\title{
A Comparison of Transplant Outcomes in Peritoneal and Hemodialysis Patients: A Meta-Analysis
}

\author{
Maozhi Tang a Tianyi Li ${ }^{\mathrm{b}}$ Hong Liu ${ }^{\mathrm{a}}$ \\ a Department of Nephrology, Southwest Hospital, Third Military Medical University, and ${ }^{\mathrm{b}}$ Department of Urology, \\ Chongqing Medical University, Children's Hospital, Chongqing, China
}

\section{Key Words}

Dialysis modality · Kidney transplantation · Graft survival ·

Patient survival · Delayed graft function · Acute rejection

\begin{abstract}
Background: Peritoneal dialysis (PD) and hemodialysis (HD) have been considered the 2 standard pre-transplant dialysis modalities in patients awaiting kidney transplantation. However, the impact of pretransplant dialysis on the short- and long-term post-transplant outcomes remains controversial. Methods: We searched PubMed, EMBASE and the Cochrane central register of controlled trials for this review. Twelve studies were identified by strict screening for the meta-analysis. Results: We found that pretransplant PD patients had a significantly lower incidence of delayed graft function than HD patients, with an OR 0.67 (95\% Cl 0.62-0.72, p < 0.05). In contrast, there was no significant difference in the incidence of acute rejection, OR $0.96(95 \% \mathrm{Cl} 0.75-1.16)$. Pretransplant PD had a better 5-year patient survival rate than HD, with a hazard ratio $0.86(95 \% \mathrm{Cl} 0.79-0.95, \mathrm{p}<0.05)$; however, there were no significant differences in the graft survival rate $(p=$ 0.08). Conclusions: We found that PD was a better choice of pretransplant dialysis modality than HD.

Video Journal Club 'Cappuccino with Claudio Ronco' at http://www.karger.com/?doi=446272.
\end{abstract}

\section{Background}

End-stage renal disease (ESRD) is a life-threatening disease that requires appropriate and sequential selection and ordering of available therapies. Dialysis and kidney transplantation are the currently used replacement therapies, and kidney transplantation is the best option to prolong the patient's life. Most patients require dialysis as they wait for transplantation; however, the impact of pretransplant dialysis on the posttransplant graft and patient survival has produced conflicting results. A number of studies have demonstrated that the modality of dialysis does not affect the outcomes [1-4]. However, other studies have indicated an increased survival for patients and grafts treated by peritoneal dialysis (PD) or, on the contrary, increased graft survival by hemodialysis (HD) [5-8], despite the fact that the 2 largest studies using national datasets in the 21 st century have yielded conflicting results $[8,9]$. From previous studies, it has been found that short-term posttransplant complications such as acute rejection (AR) and delayed graft function (DGF) have also made differences $[1,5,6$, 9-12]. In such situations, a meta-analysis can be helpful to assess whether a true difference exists; the purpose of this systematic review and meta-analysis was to explore which pretransplant dialysis modality yielded better results.

\section{KARGER}

E-Mail karger@karger.com

www.karger.com/bpu (c) 2016 S. Karger AG, Basel

0253-5068/16/0422-0170\$39.50/0
Hong Liu

Department of Nephrology

Southwest Hospital, Third Military Medical University

Chongqing 400038 (China)

E-Mail lhzhm12@163.com 
Table 1. Baseline characteristics of the included studies

\begin{tabular}{|c|c|c|c|c|c|c|c|}
\hline Author/year & Study design & Location & Number (PD/HD) & $\begin{array}{l}\text { Dialysis time before } \\
\text { transplantation } \\
\text { (PD/HD) (months) }\end{array}$ & $\begin{array}{l}\text { Follow-up } \\
\text { time after } \\
\text { transplantation }\end{array}$ & $\begin{array}{l}\text { Main } \\
\text { outcomes }\end{array}$ & $\begin{array}{l}\text { Quality } \\
\text { assessment } \\
\text { (0-9 stars) }\end{array}$ \\
\hline $\begin{array}{l}\text { Van Biesen } \\
\text { et al. [11], } 2000\end{array}$ & $\begin{array}{l}\text { Single center, } \\
\text { retrospective cohort }\end{array}$ & Belgium & $119(40 / 79)$ & $>3$ & 4 months & DGF & 6 \\
\hline $\begin{array}{l}\text { Joseph and Jindal } \\
{[10], 2002}\end{array}$ & $\begin{array}{l}\text { Single center, } \\
\text { retrospective cohort }\end{array}$ & UK & $300(183 / 117)$ & $>3$ & $\begin{array}{l}61 \pm 26 \\
\text { months }\end{array}$ & $\begin{array}{l}\text { Survival rate, } \\
\mathrm{AR}, \mathrm{DGF}\end{array}$ & 7 \\
\hline Snyder et al. [9], 2002 & $\begin{array}{l}\text { Single center, } \\
\text { retrospective cohort }\end{array}$ & $\begin{array}{l}\text { United } \\
\text { States }\end{array}$ & $22,776(5,621 / 17,155)$ & $>2$ & 5 years & Survival rate, DGF & 8 \\
\hline $\begin{array}{l}\text { Goldfarb-Rumyantzev } \\
\text { et al. [8], } 2005\end{array}$ & $\begin{array}{l}\text { Database based, } \\
\text { retrospective cohort }\end{array}$ & $\begin{array}{l}\text { United } \\
\text { States }\end{array}$ & 92,844 & $>2$ & $>10$ years & Survival rate & 8 \\
\hline Yang et al. [1], 2009 & $\begin{array}{l}\text { Single center, } \\
\text { retrospective cohort }\end{array}$ & China & $402(99 / 303)$ & $>3$ & $\begin{array}{l}30.2 \pm 15.2 \\
\text { months }\end{array}$ & $\begin{array}{l}\text { Survival rate, } \\
\text { AR, DGF }\end{array}$ & 5 \\
\hline Ardalan et al. [17], 2011 & $\begin{array}{l}\text { Single center, } \\
\text { retrospective cohort }\end{array}$ & Iran & $143(69 / 74)$ & $>3$ & 5 years & $\begin{array}{l}\text { Survival rate, } \\
\mathrm{AR}, \mathrm{DGF}\end{array}$ & 6 \\
\hline Freitas et al. [3], 2011 & $\begin{array}{l}\text { Single center, } \\
\text { retrospective cohort }\end{array}$ & Portugal & $306(38 / 268)$ & $59.5 / 33.0$ & $\begin{array}{l}29 \pm 16 \\
\text { months }\end{array}$ & $\begin{array}{l}\text { Survival rate, DGF, } \\
\text { AR }\end{array}$ & 5 \\
\hline $\begin{array}{l}\text { Courivaud et al. [19], } \\
2011\end{array}$ & $\begin{array}{l}\text { Multicenter, } \\
\text { retrospective cohort }\end{array}$ & France & $1,896(332 / 1,564)$ & NA & NA & AR & 5 \\
\hline $\begin{array}{l}\text { Schwenger et al. [7], } \\
2011\end{array}$ & $\begin{array}{l}\text { Multicenter, } \\
\text { retrospective cohort }\end{array}$ & Germany & $57,315(11,664 / 45,651)$ & $3.1 \pm 2.7 / 4.1 \pm 3.3$ & 5 years & Survival rate & 9 \\
\hline Sezer et al. [5], 2011 & $\begin{array}{l}\text { Single center, } \\
\text { retrospective cohort }\end{array}$ & Turkey & $250(70 / 180)$ & $>3$ & 5 years & Survival rate, DGF & 6 \\
\hline Molnar et al. [6], 2012 & $\begin{array}{l}\text { Database based, } \\
\text { retrospective cohort }\end{array}$ & $\begin{array}{l}\text { United } \\
\text { States }\end{array}$ & $14,508(2,092 / 12,416)$ & NA & 6 years & $\begin{array}{l}\text { Graft failure, DGF, } \\
\text { survival rate }\end{array}$ & 6 \\
\hline $\begin{array}{l}\text { López-Oliva et al. } \\
{[18], 2014}\end{array}$ & $\begin{array}{l}\text { Single center, } \\
\text { retrospective cohort }\end{array}$ & Spain & $236(118 / 118)$ & $27.9 \pm 27.9 / 50.7 \pm 67.5$ & $\begin{array}{l}102.1 \pm 63.1 \\
\text { months }\end{array}$ & $\begin{array}{l}\text { Survival rate, DGF, } \\
\text { AR }\end{array}$ & 6 \\
\hline
\end{tabular}

$\mathrm{NA}=$ Not given

\section{Method}

\section{Search Strategy}

Two independent investigators (M.T., T.L.) conducted a systematic review of published peer-reviewed research articles by searching the PubMed, EMBASE and the Cochrane central register of controlled trials databases for all years. The search was conducted using the following terms: 'peritoneal dialysis', 'hemodialysis', 'dialysis modality', 'kidney transplant*' and 'transplant outcome'. We reviewed reference lists for additional citations.

\section{Inclusion and Exclusion Criteria}

Studies were eligible for inclusion in the review if they met the following criteria: (1) randomized controlled trial (RCT) or cohort study; (2) assessed at least one of the following outcomes: patient survival, graft survival, AR, or DGF; (3) patients underwent kidney transplant after 1990; and (4) were English articles only. Studies were excluded if they met the following criteria: (1) were review papers, conference abstracts, thesis, news, and non-peer-reviewed articles; (2) the patients were children; and (3) the sample size was less than 100 cases.

\section{Quality Assessment}

Quality assessment was based on the Newcastle-Ottawa Scale [13] with the following items: (1) the exposed cohort was truly representative; (2) the cohort was drawn from the same community; (3) ascertainment of exposure; (4) outcome of interest not present at start; (5a) cohorts comparable in age; (5b) cohorts comparable on other factor(s); (6) quality of outcome assessment; (7) followup long enough for outcomes to occur; and (8) complete accounting for cohorts. All studies were rated on each indicator (1 star for 'yes' and 0 stars for 'no') for a total score between 0 and 9; the quality assessment is shown in table 1 .

\section{Data Extraction}

Two independent reviewers abstracted data from the included studies using modified Cochrane Back Review Group criteria [14]. We extracted the following information: first author and published year, region, study design, sample size, the follow-up time and posttransplant outcomes.

\section{Statistical Analysis}

All statistical calculations were performed using Stata version 12.0 (StataCorp LP, College Station, Tex., USA). We estimated the heterogeneity between studies with Cochran's Q (reported as $\chi^{2}$ 


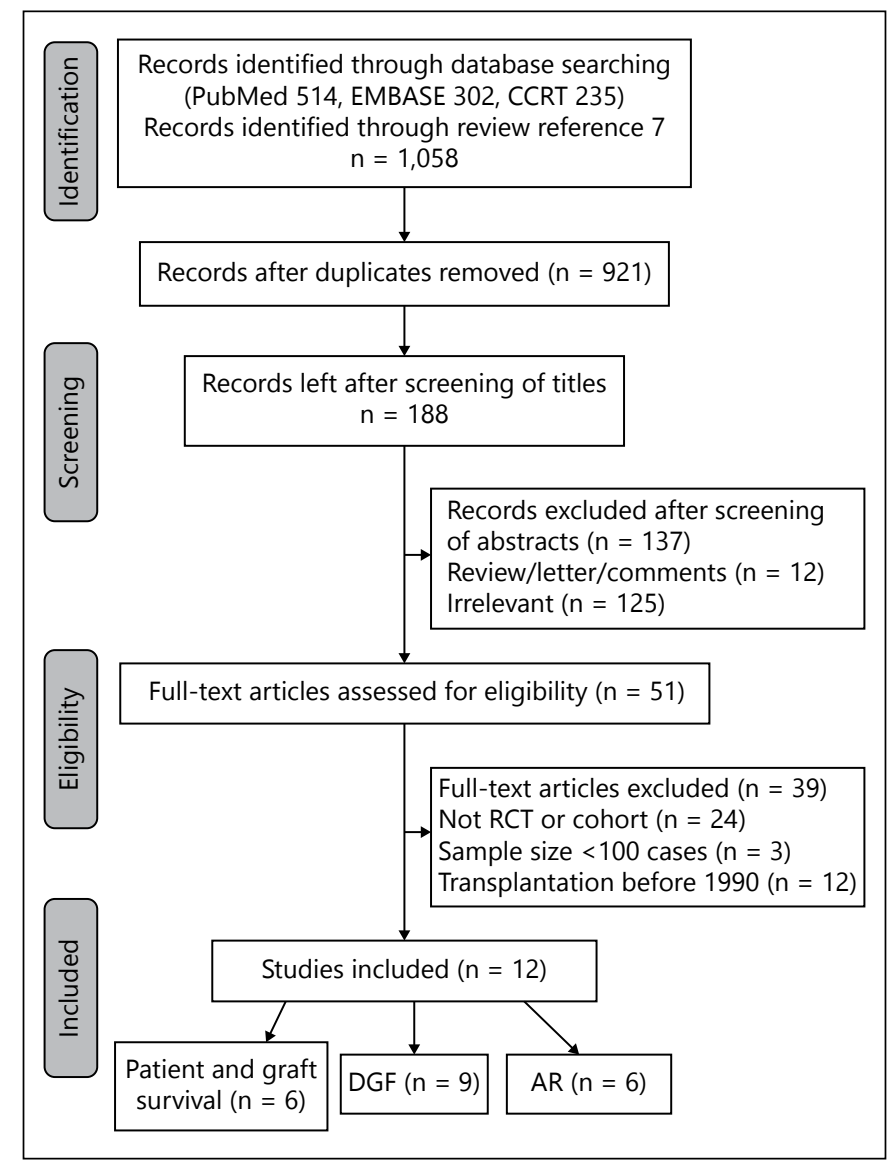

Fig. 1. Flowchart.

and $\mathrm{p}$ values) and the $\mathrm{I}^{2}$ statistic [15]. $\mathrm{I}^{2}$ does not inherently depend on the number of studies included; the suggested options included using 25, 50 and $75 \%$ to indicate low-, moderate-, and high-level heterogeneity. In meta-analyses, a random effects model using the DerSimonian and Laird method is assumed if high levels of heterogeneity are observed [15]. Hazard ratios (HRs) were used to estimate the 5-year patient and graft survival analyses. HRs and their variance for each individual study were extracted or calculated based on the published studies according to the methods described by Parmar et al. [16]. Kaplan-Meier curves were read by Engauge Digitizer version 4.1 (http://digitizer.sourceforge.net/). ORs were used to measure the risk of posttransplant complications. Publication bias was not performed because of the small sample size. Significance was set at a p value of $<0.05$.

\section{Results}

\section{Flow of Included Studies}

Figure 1 summarizes the process of identifying eligible studies. Our initial search criteria identified 1,058 articles from 3 electronic databases and hand review, and 921 studies remained after removing duplicated articles. Ti- tles were screened among the remaining 921 studies, and 733 were excluded because they were not relevant. The 188 remaining studies were screened based on the abstracts; 137 studies were excluded because 12 were reviews, letters or comments, and 125 were excluded because they were not relevant to the topic. A total of 51 studies were eligible for full-text screening, and 24 studies were further excluded because they were not RCTs or cohort studies. Three articles were excluded because of their small sample size, and the other 12 studies that included patients who underwent transplantation before 1990 were excluded. The remaining 12 studies (6 studies reported survival analysis, 9 studies reported DFG and 6 studies reported AR) were eligible for the final meta-analysis.

\section{Baseline Characteristics of the Included Studies}

Table 1 depicts the baseline characteristics of the 12 included retrospective cohort studies; they were single-center studies, 2 were multicenter studies and 2 were databasebased studies. Six studies of 187,886 ESRD patients were included in the analysis of patient survival $[6-10,17], 5$ studies of 187,586 patients included in the analysis of graft survival $[6-9,17], 9$ studies of 39,040 patients included in the analysis of DFG $[1,3,5,6,9-11,17,18]$ and 6 studies of 3,283 patients included in the analysis of AR [1,3, 10, 17-19].

\section{Short-Term Post-Transplant Complications}

DGF and AR were the main short-term posttransplant complications. Figure 2 shows the meta-analysis of DGF and $\mathrm{AR}$ for pretransplant $\mathrm{PD}$ compared with pretransplant $\mathrm{HD}$, which indicated that $\mathrm{PD}$ patients had a significantly lower risk of DGF than the HD patients with an OR 0.67 (95\% CI 0.62-0.72); however, moderate heterogeneity was observed $\left(\mathrm{I}^{2}=54.5 \%\right)$. Additionally, $\mathrm{PD}$ patients had a lower risk of AR than HD patients, yielding an OR 0.96 (95\% CI $0.75-1.16)$, and no heterogeneity was observed $\left(\mathrm{I}^{2}=\right.$ $0 \%)$; however, the difference was not significant.

\section{Long-Term Outcomes of Transplantation}

Figure 3 shows the pooled HR of posttransplant 5-year patient survival rates for pretransplant PD compared with pretransplant $\mathrm{HD}$. We found that $\mathrm{PD}$ patients had a higher 5-year patient survival rate than HD patients, yielding an HR $0.86(95 \%$ CI $0.79-0.95, \mathrm{p}<0.05)$ but with high heterogeneity $\left(\mathrm{I}^{2}=79.3 \%\right)$.

Figure 4 shows the pooled HR of posttransplant 5 -year graft survival rates for pretransplant PD compared with pretransplant $\mathrm{HD}$, which indicated no significant differences between the 2 modalities, with an HR 0.92 (95\% CI 0.84-1.01, $\mathrm{p}=0.08$ ). Additionally, Goldfarb-Ru- 


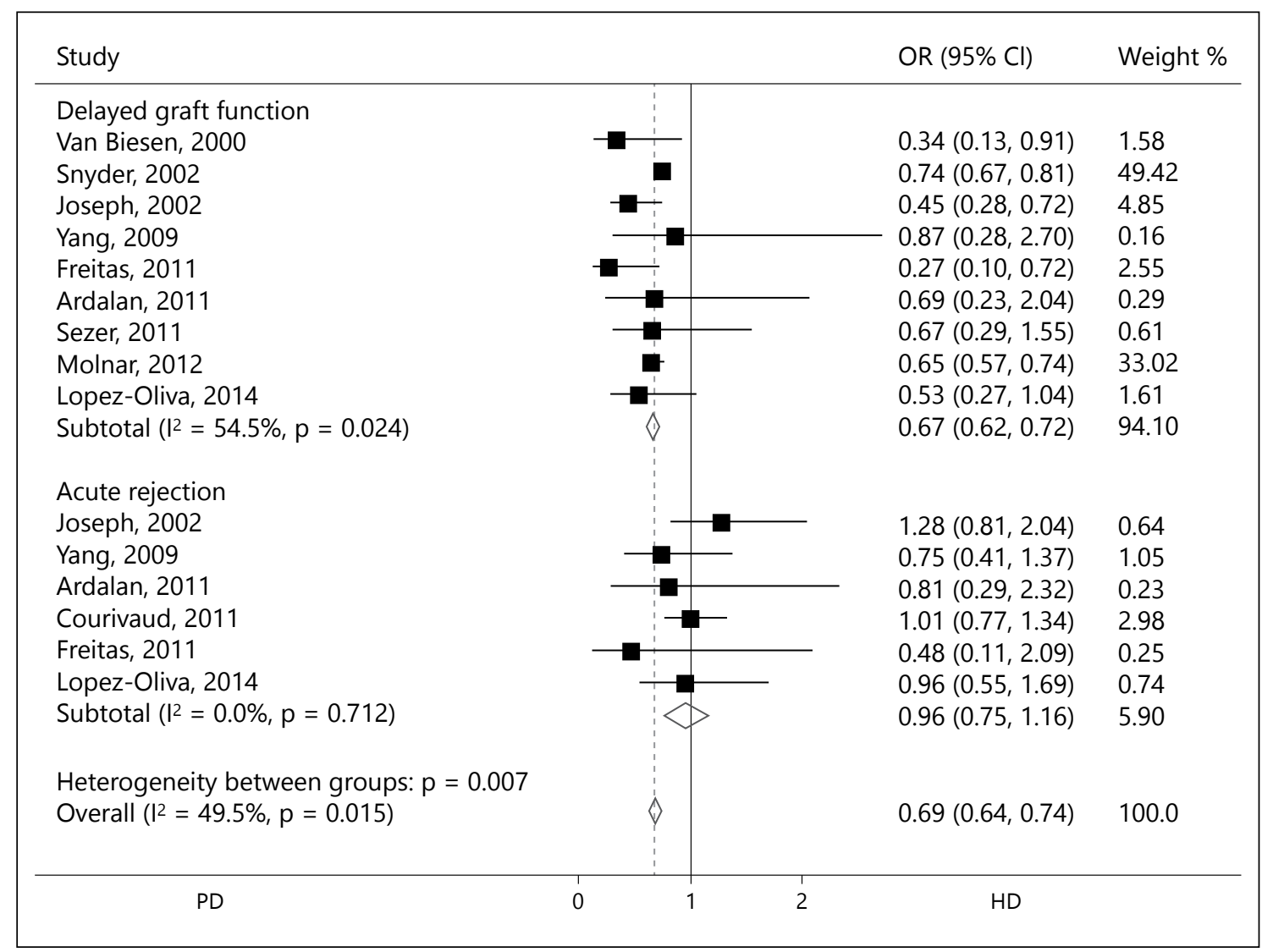

Fig. 2. Risk of DFG and AR in PD vs. HD.

myantzev's study with 92,844 patients designed a 10-year follow-up evaluation that suggested that $\mathrm{PD}$ patients had a protective effect for graft survival (HR 0.97, p < 0.05) and better recipient survival (HR 0.96, p < 0.05) compared to HD patients [8].

\section{Discussion}

The first meta-analysis on this topic was conducted by Winchester et al. [20] in 1993 to evaluate the effects of pretransplant dialysis on the posttransplant outcomes. However, there have not been updated analyses for 20 years; hence, the attempt to compose a new study to explore the question. Similar to all observational meta-analyses, selection bias cannot be definitively excluded in these retrospective cohort studies, and the diversity of baseline characteristics among the studies led to heterogeneity.

Confounding factors in each study such as age, body mass index, time of dialysis, frequency of dialysis, year of transplantation, geographical region and use of immunosuppressive drugs could not be well controlled or matched.

Studies have shown that chronic renal insufficiency leads to a micro-inflammation condition through accumulation of inflammasomes and metabolites and that artificial membranes used in HD could increase free radical production by activating complement factors and phagocyte leucocytes; this oxidative stress contributes to DGF $[21,22]$. On the other hand, PD patients had better cellmediated immune states and less oxidative stress than HD patients $[23,24]$. Additionally, PD modality had a protective effect on renal functional recovery after transplantation due to optimized fluid status [11]. All of the factors mentioned above may have been associated with the higher incidence of DFG in HD patients vs. PD patients. One other explanation for this result was the possibility that residual native kidney function was better preserved in PD patients than in HD patients $[25,26]$.

$\mathrm{HD}$ as a pretransplant modality may have a higher incidence of AR because patients receiving artificial membranes in HD may induce stronger immune responses 


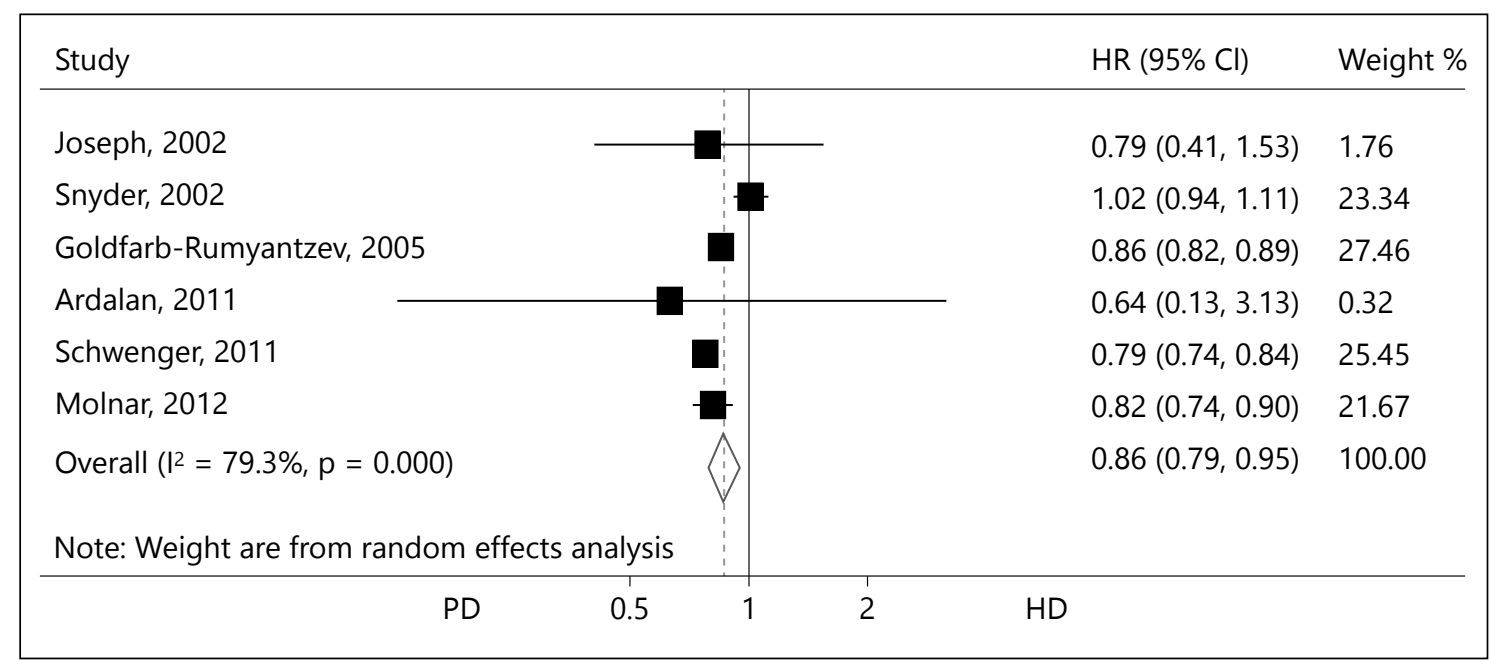

Fig. 3. HRs of 5-year patient survival in PD vs. HD.

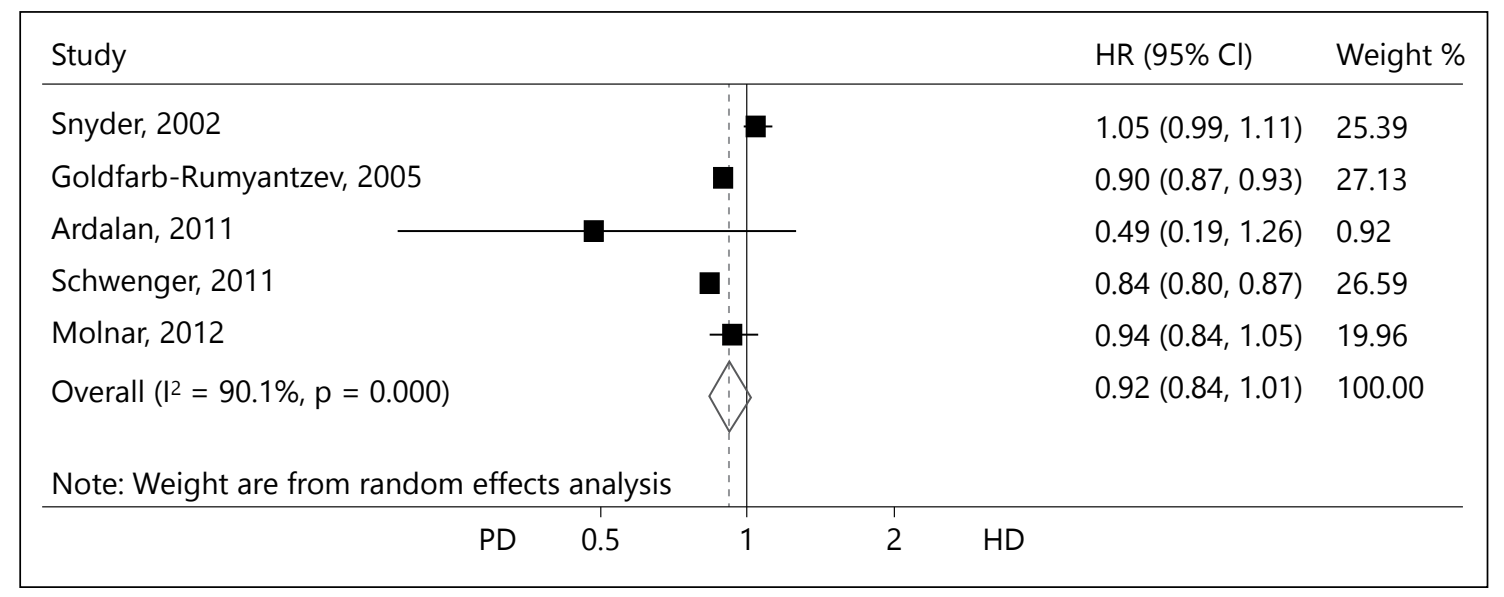

Fig. 4. HRs of 5-year graft survival in PD vs. HD.

than patients receiving PD. Furthermore, HD patients with a higher incidence of DGF may contribute to the increased incidence of $\operatorname{AR}[27,28]$. On the other hand, ESRD patients undergoing chronic HD exhibit impaired cellular immune response with a marked reduction in the naïve and central memory subsets of CD4+ and CD8+ T cells, and the total circulating $\mathrm{T}$ cells are significantly lower in HD than in PD patients [29, 30]. Furthermore, PD patients are typically accompanied by greater biochemical and hematological stability due to improved nutritional balance and social independence enjoyment, consequently preventing metabolic and nutritional harm to the immune system, with a better immunologic state contributing to a higher incidence of $\mathrm{AR}$ in $\mathrm{PD}$ patients than in HD patients [20, 30-33]. Hence, the debate has not yet reached any consensus. However, our meta-analysis found that there were no significant differences between the 2 pretransplant modalities in the incidences of $A R$, with an OR 0.96 (95\% CI 0.75-1.16), which may have benefited from the use of immunosuppressive agents.

Snyder et al. [9] in a study of 22,776 patients suggested that PD patients had a higher risk of graft failure than HD patients during the first 3 months after transplantation with an adjusted OR 1.23 (95\% CI 1.09-1.39). These results could be explained by a higher incidence of infections and early graft thrombosis in PD patients [33-36]. Typically, PD patients have a better immunologic state, which could have an adverse effect on the outcome of graft survival [30]. However, in our meta-analysis of 5-year observations, we found no significant differences in the graft 
survival rate between the 2 dialysis modalities with an $\mathrm{HR}$ 0.92 (95\% CI 0.84-1.01, $\mathrm{p}=0.08$ ). In our meta-analysis, we found that $\mathrm{PD}$ patients had a better 5 -year patient survival than HD patients, with an HR 0.86 (95\% CI 0.79-0.95, $\mathrm{p}<0.05$ ); this was associated with a better quality of life, better nutritional status and fewer blood transfusions in PD patients. Additionally, the use of novel immunosuppressive drugs contributed to prolonging a patient's life [37-39]. One limitation of the study was that we did not evaluate long-term, posttransplant complications such as posttransplant diabetes mellitus, malignancy and cardiovascular accidents, which are still under debate.

In conclusion, we found that pretransplant dialysis does influence the short- and long-term complications after kidney transplantation and that PD as a pretrans- plant dialysis modality seems to be a better choice than HD. However, a 5-year observation was not sufficient to evaluate graft and patient survival; 10-year follow-up studies are therefore needed, especially for prospective studies.

\section{Acknowledgments}

We thank Prof. Zhao Yong for his assistance in searching for publications.

\section{Disclosure Statement}

The authors do not have any possible conflicts of interest.

\section{References}

1 Yang Q, Zhao S, Chen W, et al: Influence of dialysis modality on renal transplant complications and outcomes. Clin Nephrol 2009;72: 62-68.

2 Bleyer AJ, Burkart JM, Russell GB, et al: Dialysis modality and delayed graft function after cadaveric renal transplantation. J Am Soc Nephrol 1999;10:154-159.

3 Freitas C, Fructuoso M, Martins LS, et al: Posttransplant outcomes of peritoneal dialysis versus hemodialysis patients. Transplant Proc 2011;43:113-116.

4 Pérez Fontán MP, Rodriguez-Carmona A, Garcia Falcon T, et al: Renal transplantation in patients undergoing chronic peritoneal dialysis. Perit Dial Int 1996;16:48-51.

5 Sezer S, Karakan S, Özdemir Acar FN, et al: Dialysis as a bridge therapy to renal transplantation: comparison of graft outcomes according to mode of dialysis treatment. Transplant Proc 2011;43:485-487.

6 Molnar MZ, Mehrotra R, Duong U, et al: Dialysis modality and outcomes in kidney transplant recipients. Clin J Am Soc Nephrol 2012; 7:332-341.

7 Schwenger V, Dohler B, Morath C, et al: The role of pretransplant dialysis modality on renal allograft outcome. Nephrol Dial Transplant 2011;26:3761-3766.

8 Goldfarb-Rumyantzev AS, Hurdle JF, Scandling JD, et al: The role of pretransplantation renal replacement therapy modality in kidney allograft and recipient survival. Am J Kidney Dis 2005;46:537-549.

9 Snyder JJ, Kasiske BL, Gilbertson DT, et al: A comparison of transplant outcomes in peritoneal and hemodialysis patients. Kidney Int 2002;62:1423-1430.

10 Joseph JT, Jindal RM: Influence of dialysis on post-transplant events. Clin Transplant 2002; $16: 18-23$.
11 Van Biesen W, Vanholder R, Van Loo A, et al: Peritoneal dialysis favorably influences early graft function after renal transplantation compared to hemodialysis. Transplantation 2000;69:508-514.

12 Kitada H, Doi A, Nishiki T, et al: Short-term outcome of renal transplantation treated with pre-transplant peritoneal dialysis. Dial Transplant 2010;39:148-150.

13 Wells G, Brodsky L, O'Connell D, et al: Evaluation of the Newcastle-Ottawa Scale (NOS): An Assessment Tool for Evaluating the Quality of Non-Randomized Studies. Barcelona, XI Cochrane Colloquium: Evidence, Health Care and Culture, 2003.

14 van Tulder M, Furlan A, Bombardier C, Bouter L, et al; Editorial Board of the Cochrane Collaboration Back Review Group: Updated method guidelines for systematic reviews in the Cochrane collaboration back review group. Spine (Phila Pa 1976) 2003;28:12901299.

15 Huedo-Medina TB, Sánchez-Meca J, MarínMartínez F, et al: Assessing heterogeneity in meta-analysis: $\mathrm{Q}$ statistic or $\mathrm{I}^{2}$ index? Psychol Methods 2006;11:193-206.

16 Parmar MK, Torri V, Stewart L: Extracting summary statistics to perform meta-analyses of the published literature for survival endpoints. Stat Med 1998;17:2815-2834.

17 Ardalan M, Etemadi J, Ghabili K, et al: Effect of dialysis modality on transplantation outcome in living-donor renal transplantation. Nephro Urol Mon 2011;3:202207.

18 López-Oliva MO, Rivas B, Pérez-Fernández E, et al: Pretransplant peritoneal dialysis relative to hemodialysis improves long-term survival of kidney transplant patients: a singlecenter observational study. Int Urol Nephrol 2014;46:825-832.
19 Courivaud C, Ladriere M, Toupance O, et al: Impact of pre-transplant dialysis modality on post-transplant diabetes mellitus after kidney transplantation. Clin Transplant 2011;25: 794-799.

20 Winchester JF, Rotellar C, Goggins M, et al: Transplantation in peritoneal dialysis and hemodialysis. Kidney Int Suppl 1993;40:S101S105.

21 Barany P, Divino Filho JC, Bergstrom J: High C-reactive protein is a strong predictor of resistance to erythropoietin in hemodialysis patients. Am J Kidney Dis 1997;29:565568 .

22 Conti G, Amore A, Chiesa M, et al: Procalcitonin as a marker of micro-inflammation in hemodialysis. J Nephrol 2005;18:282-288.

23 Martin-Mateo MC, del Canto-Jafiez E, Barrero-Martinez MJ: Oxidative stress and enzyme activity in ambulatory renal patients undergoing continuous peritoneal dialysis. Ren Fail 1998;20:117-124.

24 Schwabe RF, Engelmann H, Hess S, et al: Soluble CD40 in the serum of healthy donors, patients with chronic renal failure, haemodialysis and chronic ambulatory peritoneal dialysis (CAPD) patients. Clin Exp Immunol 1999; 117:153-158.

25 Lysaght MJ, Vonesh EF, Gotch F, et al: The influence of dialysis treatment modality on the decline of remaining renal function. ASAIO Trans 1991;37:598-604.

26 Misra M, Vonesh E, Van Stone JC, et al: Effect of cause and time of dropout on the residual GFR: a comparative analysis of the decline of GFR on dialysis. Kidney Int 2001;59:754-763.

27 Troppmann C, Gillingham KJ, Benedetti E, et al: Delayed graft function, acute rejection, and outcome after cadaver renal transplantation. The multivariate analysis. Transplantation 1995;59:962-968. 
28 Sanfilippo F, Vaughn WK, Spees EK, et al: The detrimental effects of delayed graft function in cadaver donor renal transplantation. Transplantation 1984;38:643-648.

29 Yoon JW, Gollapudi S, Pahl MV, et al: Naive and central memory $\mathrm{T}$-cell lymphopenia in end-stage renal disease. Kidney Int 2006;70: 371-376.

30 Guillou PJ, Will EJ, Davison AM, et al: CAPD - a risk factor in renal transplantation? Br J Surg 1984;71:878-880.

31 Langhoff E, Ladefoged J: Improved lymphocyte transformation in vitro of patients on continuous ambulatory peritoneal dialysis. Proc Eur Dial Transplant Assoc 1983;20:230-235.

32 Giangrande A, Cantu P, Limido A, et al: Continuous ambulatory peritoneal dialysis and cellular immunity. Proc Eur Dial Transplant Assoc 1983;19:372-379.

33 Vats AN, Donaldson L, Fine RN, et al: Pretransplant dialysis status and outcome of renal transplantation in North American children: a NAPRTCS study. North American pediatric renal transplant cooperative study. Transplantation 2000;69:1414-1419.

34 van der Vliet JA, Barendregt WB, Hoitsma AJ, et al: Increased incidence of renal allograft thrombosis after continuous ambulatory peritoneal dialysis. Clin Transplant 1996;10(1 pt 1):51-54.

35 Murphy BG, Hill CM, Middleton D, et al: Increased renal allograft thrombosis in CAPD patients. Nephrol Dial Transplant 1994;9: $1166-1169$
36 Passalacqua JA, Wiland AM, Fink JC, et al: Increased incidence of postoperative infections associated with peritoneal dialysis in renal transplant recipients. Transplantation 1999;68:535-540.

37 Juergensen E, Wuerth D, Finkelstein SH, et al: Hemodialysis and peritoneal dialysis: patients' assessment of their satisfaction with therapy and the impact of the therapy on their lives. Clin J Am Soc Nephrol 2006;1:1191-1196.

38 Russo GE, Morgia A, Cavallini M, et al: [Quality of life assessment in patients on hemodialysis and peritoneal dialysis]. G Ital Nefrol 2010;27:290-295.

39 Rubin HR, Fink NE, Plantinga LC, et al: Patient ratings of dialysis care with peritoneal dialysis vs. hemodialysis. JAMA 2004;291:697-703. 